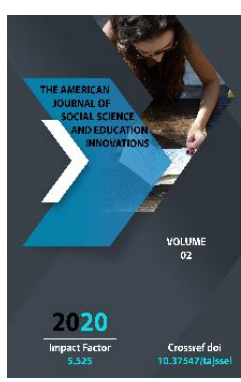

\section{Qatar Novelistic And Features Of Its Accelerated Development}

\author{
Shahlo Irgashbaevna Akhmedova \\ Candidate Of Philology, Head Of Organization Department Research Activities Gifted \\ Students, Tashkent State Institute Of Oriental Studies, Tashkent, Uzbekistan
}

Journal Website:

http://usajournalshub.c om/index,php/tajssei

Copyright: Original content from this work may be used under the terms of the creative commons attributes 4.0 licence.

\title{
ABSTRACT
}

The article notes that the development of modern prose in Qatar fits well with the concept of "accelerated development of literature." Thanks to technological progress during the rapid economic growth of the Gulf countries - Kuwait, Bahrain, Qatar, the United Arab Emirates and Oman, the Arabic-speaking countries of Khaleej (Gulf) quickly became acquainted with world culture and the world literary process, primarily with the literary experience of culturally developed Arab countries such as Egypt, Syria, Lebanon and Iraq. The author of the article, using the example of the short story genre, traces the stages of its development from descriptive short stories with weak conflicts and a naive plot with an edifying and didactic tendency to mature short stories that fit into the concept of a modern short story. In the literary arena of the 70s of the XX century such masters of the word as Ibrahim Sucr al-Marikhi, Kulsum Jaber, Fatima al-Turki and others appeared who made a great contribution to improving the short story genre in Qatar and first addressed the important problems of contemporary reality. One of such important problems, according to the author, is the problem of the emancipation of a Qatari woman - her right to have her own voice, get an education, and choose a profession.

In its spasmodic development, the Qatari short story was also influenced by the modernist tendency due to acquaintance with Western literature. Short stories appeared that are distinguished by psychologism, the non-uniformity of the characters depicted, and a special attitude. Writers often using modernist techniques - a stream of consciousness, associative thinking, subtext, etc. convey the emotional crisis of their hero, his painful spiritual quest. By the beginning of the XXI century, new bold young people who had joined the Qatari literature, caused the evolution of socioethical short stories to action-packed short stories, which raised social problems that were still hushed up . 


\section{KEYWORDS}

World literary process, contemporary prose, Al-Khaleej, Qatari prose, realism, romanticism, story, method.

\section{INTRODUCTION}

The short story takes one of significant places in the history of the Arabian literature. In some countries of the Persian Gulf - in Qatar, Oman, the United Arab Emirates - the story genre is the most developed genre that has been formed and improved over more than half a century of literature history of these countries from the second half of the XXbeginning of the $X X I$ centuries. Novelistics is an integral part of the modern literature of these countries at the present stage.

Religious and ethnic unity, common national customs and traditions of peoples, the similarity of cultural processes, as well as the common nature of the social changes of such Arab countries as Qatar, Oman, the United Arab Emirates are reflected in the development of the literature of these countries, which in their development follow a relatively similar path. The formation of modern literature in these countries accelerated in the last quarter of the 2oth century, and in the 21st century it became fully consistent with the theory of "accelerated development of fiction in the countries of the Arabian Peninsula" [1: 3].

The awakening of national self-awareness, the desire of peoples for national liberation and the transformation of these countries into rich states as a result of profits derived from oil, led to radical socio-economic changes. And these factors, in turn, have become a kind of impetus for the development of fiction and the emergence of modern genres.

\section{THE MAIN RESULTS AND FINDINGS}

In the search for new forms and expressive means, the writers of the Arabian Gulf countries turned first of all to the experience of Egypt, Syria and other culturally developed Arab countries, as well as the literature of the West and America. However, the assimilation of this literature in a very short time led to an interesting literary situation and contradictions. They expressed themselves in a mixture of various literary trends and artistic methods.

In Qatar, related to the Arab countries of the Persian Gulf, the "accelerated development of literature" is also reflected in literature, but especially in novelistic works.

As noted by the famous Qatari scholar and literary critic Mohammed Abdurahim Kafud, in Qatar, the chief editor of the al-Aruba newspaper, Yusuf Nemat, turned to writing the modern story for the first time. This newspaper was the first local newspaper to be published in the late sixties. In 1962, the first short story by Yusuf Nemat "Daughter AlKhalidzh" (ال خل يخ بـ نت) was published in this newspaper. Al-Khalidzh - the Arabic name for the Persian Gulf. 
Then, under the same name, the first collection of his short stories was released. In 1970 a collection of short stories was published entitled "Beirut meeting" ( لـ لـاء (ب يروت), in 1971 - a collection of "Screaming Boy" (الهايد ت الولد د). The literary scholar Muhammad Abdurahim Kafood gives the following assessment of these collections: "Descriptive presentation and rhetoric prevail in these stories, as well as information material, which however does not express the realities of Qatar. Yusuf Nemat, being influenced by the stories of other Arab countries, lived in the midst of their stories. [2: 9]. But, despite this, Hassan Rashid and Murod Mabruk became his followers " [3: 18-19].

The stories of these writers were not distinguished by the complexity of the plot, they were somewhat naive, distinguished by descriptiveness, didactics, but they appeared as a new type of story, as some literary scholars noted. Moreover, some of them considered these stories to be the starting point in writing the Qatari story. The debate about exactly when a new type of story appeared in Qatar is still not over. And that is why when they talk about these first ones, they are considered the basis for the formation of the story.

The literary scholar Kafud in his following thoughts is not so categorical: "Maybe the first attempts to write stories in Qatar were precisely the attempts of Yusuf Nemat. The first story appeared, "The daughter of alKhalidzh," but neither I nor the writer himself still have a copy of this story. However, we can say that this story is not distinguished by perfection and maturity, as according to the following stories of the novelist. The stories that were published in the first two collections are more like informative journalistic articles or naive everyday simple stories about people.
However, due to the large number of dialogues, the latest collection, The Screaming Boy, is similar to a play, and the writer, through the use of dialogues, displays various dialects. Indeed, we cannot be satisfied with the quality of these stories and cannot consider them to be fully formed works "[5: 128].

The great socio-political changes that took place in the country in the early 6os changed the way of thinking and the values of society. At that time, the results of various processes affecting the life of the nation were reflected in various forms, approaches and thinking about reality. The reason for this is that during this period Qatar was not so developed, culturally as other countries of Khalidzh, educational work was not put at the proper level. There was no work to reform the educational system as in other countries of Khalidzh (in Kuwait, Bahrain), sports clubs and libraries did not operate, there were no conditions for opening active scientific societies. The country's population was not familiar with cultural media. This situation lasted until the 70s, and only in the early 70 s did the first publishing houses and the press appear. The reason for their appearance was the activity of commercial-social layers, which formed after the 50-60s in the bowels of the middle stratum of the population.

In short, the reason for the late formation of Qatar's short stories is that in all aspects of a cultural society - in institutions, social strata, among intellectuals and students - cultural and educational development is belated. We see that in the $70 \mathrm{~s}$ there were many attempts to write stories, however, the stories of this period, as noted above, were one-sided in terms of composition, they had many elements of rhetoric and didactics, they were inherent in the method of photographing and 
the method of direct presentation of reality, but the breadth of the range in the choice of subjects of works is already outlined.

Central themes of the stories: unhappy love. high price of a fee (mahr) for a bride, early marriage of underage girls, marriage of convenience, negative attitude towards foreigners from Asian countries and even foreign Arabs. In a word, all these stories are devoted to various problems of social inequality.

This stage plays a historically important role in the development of Qatar short stories. It was at this stage that a generation of young writers entered the literary scene, such as Ibrahim Sukr al-Marikhi, Abdullah al-Husayniy, Kulsum Jabr, Bahiya Yusuf al-Malikiy, Ahmad Abdul Malik, Khalifa Aid al-Kabisiy, Ibrahim alSadiz, Abdulaz al-Sadat wa Mei Salim, who later became famous representatives of the short stories of Qatar.

In improving the short stories of Qatar, a great merit belongs to the role of the writer Kulsum Gills. Her method was originally romantic, the writer's works were distinguished by an individualistic attitude and a restless search for herself, her "I".

The first works of the writer began to be published in local newspapers since the 70 . The first storybook, "You, the silence of the forest and suspicion," was published in 1978. In her stories, the writer conveys her anxieties and worries, sorrows and hopes, dreams. In her stories written during this period, artistic signs of the genre are visible, they show the character, worldview of the heroes, environment

Although in the early 70s the names of many novelist writers were mentioned, among them there are no such prominent names as Kulsum Gill. In the 80s, new voices began to sound in the short story, mainly the voices of women. Writers such as Um Aksam (Fatima al-Turki), Lulu al-Masnad, Hissa al-Jabr and Maisa al Khalifi contributed to the development of Qatar literature. These writers participated in the development and improvement of the poetry of the story genre, in their peculiar style depicted social and social issues, backwardness and stagnation, different living conditions of their contemporaries.

Of course, the main topic addressed to the writers was the search for ways to free women from the traditions and customs that keep women "in chains", deprive them of their freedom of voting, choice of profession, and the right to work. In many cases, when approaching these topics, there is a choice of an interesting plot and enrichment of works with various images.

However, in the 8os there were many stories written by young writers of Qatar, which were similar to each other and their level was relatively low. The reason for the mass publication of such stories was, firstly, the very strong desire of young novelists to stand out as a writer, and secondly, these publications were specially supported by the National Assembly on Culture, Art and Heritage, which served as a kind of shield for young writers to protect, stimulate and financially support.

A large role in the development of the story genre in Qatar was played by the collection of Kulsum Jaber, "The Pain of an Arab Woman". The first publication of the collection dates back to 1989, after which he published several more editions. 
The collection of Kulsum Jaber, "The Pain of an Arab Woman" (1989), according to Arab literary critics, is "a qualitative turning point in the history of a short story in Qatar."

In his stories, Kulsum Jaber tries to solve the problem of relations between men and women in the Qatari society, or rather, in all the Arab countries of the Persian Gulf zone. The writer points out some factors contributing to failure in these relationships: age difference, parental intervention, adherence to obsolete traditions. Kulsum Jaber depicts the reality of a Qatari woman and her experiences through the desire to establish her identity in the surrounding conservative society.

From the point of view of understanding the position of the writer, the story "The Logic of Love and Hate" is very interesting. The story is built in the form of an internal monologue, where individual fragments of the dialogue of two friends intersperse. The heroine of the story, a young girl, watches with her eyes the ant crawling up along a straight path, and carefully listens to her friend's words addressed to her:

"I do not think that those who think according to your logic about life become successful people. There is no way to change being ... one should live according to the established standards by which society lives. To merge with him, to obey his clear, healthy decisions". [5]

The heroine is trying to delve into the arguments of her friend, who, in turn, is trying to inspire her with humility, motivating her to live according to the rules of society in the name of the logic of life. But the words of her friend do not have the proper effect on the heroine of the story, inside her everything is rebelling, she does not want to live according to the norms of behavior established by Muslim society:

"I hate decisions made. Why are they published? For the well-being of whom? Who can say that I am balanced and smart? I am surprised. When someone sticks such labels. Where does the tranquility that so colors my face come from? And the volcano that is raging in the depths of my soul? "

The heroine continues to follow with her eyes the movement of the ant, which changes its direct path to a zigzag movement, and makes sure that it is right. Life cannot be lived, guided by the same norms and principles, each new era brings with it innovations that must be introduced into society.

In addition to stories, Kulsum Jaber writes articles on literature and criticism. She believes that literary criticism is an artistic creation that requires a lot of effort and effort to analyze a work.

The writer says the following about the short story genre: "Recently, I have been observing the development of a short story. There were stories that had realistic and romantic shades, as well as incomplete, so-called "open-ended" stories that did not fit into the framework of one ordered form, and depart from traditional foundations. They are expressed in prose, having a poetic spirit ... Most of these stories relate to the general life phenomena and psychological conditions of a person - in sadness, in excitement, tension - which he experiences in a world where he feels his loneliness"[5].

Judging by these words, Kulsum Jaber, in the 80 s of the twentieth century, when the short story genre in Qatar was in the process of 
formation, it already had elements of modernism, when a person feels alone in a world of chaos.

The following statement of the writer indicates that she adheres to the aesthetics of modernism in her work, when the artist is free in her fantasies, and does not seek to reflect reality: "I do not have my own direction and a certain method in creating the story. This is because the writer, who is engaged in creative activities, is closer to the subconscious and instinct than to art, which relies on certain criteria and norms. The birth of a literary work takes place in an irrational way, in which the prescribed rules are broken and old plans are violated" [5].

A comparative artistic analysis of the stories written by men and women writers in Qatar shows that, where the issue of emancipation is raised, women writers are better at writing techniques and techniques.

Along with poetic language, they use various means of narration. In the women's story, Arab critics note, the national coloring is better shown.

The artistic skill of the young novelists was highly encouraged, although haste was often seen in them, and they did not possess sufficient skill and experience.

However, if you take a look at the visual and expressive means, the artistic structure, the creation of images of heroes, the choice of plot, image methods, the structure of dialogs and other artistic searches in the works of the late 80 s - early 90 s of the XX century, we can conclude about the acquisition extensive experience in this genre of creativity.
Naturally, the Qatari novelists differ from each other in the artistic power of the image, creative potential and literary talent in creating images of heroes, choosing a plot. The famous novelists feel the maturity and sufficiency of personal experience, which is an undoubted help in creating stories.

A collection of City Windows (لش باب يك) (الـ مدي نة) by Zafira al-Hajiri (الـ اجرى ظاف ر) and a

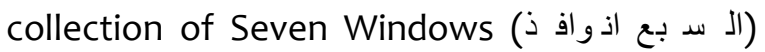
City al-Azba (الل عذب ة صد بـ نة) were published in 2003. Both collections were published by the National Assembly for Culture and Art of Qatar.

Along with this national collection of culture and art of Qatar, 3 collections of Jamal Faiz (ف اي ز جمال) and 1 collection of Hassan Rashid were published.

The collection of the writer Fatima al-Qivari ب دائة) “Another Beginning” (ال كواري ف اطمة) اخرى), shows that this writer has the undoubted talent in creating the genre and story.

If we talk about the modern writer Muhsin Fahd al-Hajiri, then he belongs to the category of romantic novelists, his romance lies in the choice of topic, method and approach to the problem, especially the conclusion of his stories is based on romantic elements. He published three collections of short stories: 1996 - The Alert "(ال بلأغ غال)" 1997" The

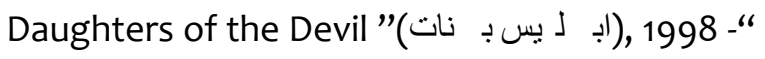
Shy "(ع لـ يك حرام).

The first attempts of the writer Muhsine Fahd al-Hajiri in short stories were successful and supported by the public. In the 90s, the writer published three collections. The preface to his collection, The Alert, was written by such famous writers as Muhammad Abdurahim Kawood, Hisam al-Khatib (Syrian literary 
critic), Murad Mabruk, poet Muhammad Kutba and Abdullah al-Imadiy.

Another novelist, Ahmad Abdul Malik, in his collection "405th Room" [6] showed the best examples of the story genre. His mastery of artistic depiction is felt from the very beginning in the dialogs and in the speech of his characters. He is a writer of a realistic direction, in depicting the relations of people, he shows the main aspects of these relations, as well as their complexity, his realism is directly related to social problems. Along with this, in the collection, the writer raises the problem of relations between men and women, mainly within the framework of family life. His method is based on a subtle depiction of the psychological state and on an attractive and interesting plot. In all collections, Ahmad Abdul Malik, especially in the collections of "405-room" and "Women's Papers" [7], covers complex social problems, depicts human experiences, unrest. He depicts the relationship between a man and a woman with skill and artistic power based on social analysis. If the writer Muhsin Fahd al-Hajiri covers open relationships through showing the human character in various situations, then the writer Jamal Faiz, when approaching the painful traditional issues that have been preserved from ancient times, depicts how new material changes are reflected in the fate of the heroes.

Social reality occupies a large place in short stories. In it we see a direct reflection of reality, sometimes they are laconic and optimistic, sometimes they are "wingless" in the stories of Sita al-Azba, the spirit of sadness and hopelessness reigns in them. This spirit is based on sensory connections in their various manifestations, on severity, on the destruction of the family, on how the human spirit gives in to customs and traditions, as a result of spiritual slavery and backwardness. Often this is expressed through symbols and hints, which is evidence of the emergence of modernist trends in Qatar's short stories. In these stories, a search for forms takes place, experiments are made through the use of various presentation techniques. Through psychological analysis, the heroes suffer through a stream of consciousness, the changes that occur with them as a result of spiritual searches. The writers who strove for a deep image of the person faced the task of searching for new visual expressive means, methods for portraying a partial defeat or destruction of love and family life.

Along with this, the Arabian narrative did not become subjective, like the Western one. There is no complete renunciation of the realistic method of depiction in it, the novel remained within the framework of the legacy and traditions of narrative presentation and in a realistic structure, and in a fantasy, and figuratively abstract direction, that is, the Arabic story remained true to its absolute moral concepts, when depicting the narrator's gaze to the world, the reflection of contradictions, struggles.

At the present stage, Qatar's short story writing and characterization of reality is developing on the basis of its national realities, however, it imitates imitation and copying to other literature, there are strong trends in the use of artistic experience and discoveries of writers around the world. Excessive tendency to social analysis, sometimes leads to a decrease in artistry in works, they become just an expression of reality and reflection, a mirror of reality.

Currently, in Qatari stories, the central issue is the question of creative search and the experience of artistic depiction. The Arabic 
story in Qatar is trying to get out of the tradition, this is manifested in violating the boundaries of time and space, in changing the structure of the plot, in the desire to abandon the plot, in the loss of the author ("the death of the author"), abstracting, in the widespread use of oral folk art, the use of dialects, poetic techniques in prose and in complementing the text with various foreignlanguage elements.

A certain influence of this experience is felt in the following 3 collections of short stories. These experiments were successful and became a literary phenomenon. These stories concentrate a lively look and artistry. These are collections of short stories - Hoody anNaimi “Denial” (بـ اط يل) [8], Nuri Mohammed Faraj “Idol" (الـوطم) [9] and Dalal Khalifa "I am Jasmine (ال يا سد يـ نة انـا)" [10]. An important sign of the artistic maturity of these three collections is a lively look at reality and its masterful image through various artistic images.

\section{CONCLUSION}

As a conclusion, we can say that the modern short story of Qatar, at the stage of its development, is undergoing literary and artistic processes that took place in the 6os of the XX century in Egypt, Syria, Lebanon, Tunisia, Algeria and other Arab countries.

Whereas the rhetorical, informational style and method of presentation predominated in the works of the older generation of novelists who created their works in the 60-70s of the 2oth century, the middle-aged novelists (Kulsum Gills, Umm Aksam) reflect the inner world of the individual and her spiritual correspondence to the surrounding world.
The significance of the young generation of novelists (Huda al-Naimi, Jamal Fayyiz, Mukhsin al-Hajari) who create their works from the late 80 s - early $90 \mathrm{~s}$ is that they showed courage by raising socio-moral problems about which the older and middle generations of short stories were silent. They approached with all responsibility the raising of problems (studying abroad, the situation in prisons, the state of persons with disabilities), which were still hushed up in Qatari society.

The quality that distinguishes young novelists lies in the fact that they live by the general social concerns of society, focus on them and try to portray them in their works.

At present, the short story of Qatar is at the stage of accelerated development and is striving to be in tune with the world literary process.

\section{REFERENCES}

1. Suvorov M.N. Hudojestvennaya proza Yemena (K probleme uskorennogo razvitiya) literatur starn Aravii) (Artistic prose of Yemen (On the problem of accelerated development)) Avtoref.dok... diss... Sankt-Peterburg, 2001. -S3

2. Muћammad 'abdal-raћi:m Ka:fu:d. alqișșa al-qațariįia. (Qatar story) Inša:u-ttațaûûur. da:r qațari bin al-fağğa:a du:ћa, 1996.

3. Hasan raši:d ûa mada:r mabru:k. ğidiįiatu-I -'ağz ûa-I - fíl fi:-l-qișșa-I -ași:ra fi: Qațar. (The deficit and the elephant in the tenth story in Qatar) ișda:ra:ti-I -mağlis. muța:ba‘a ri:nu:da. 1999

4. Aš-šuba:ț 'abdalla aћmad. Udaba:' fi:hali:ğ al-arabi - al-kuûa.jit.( Writers in 
the Arabian Gulf) dar al-ûațaniį.ja alğadi:d lin-našr ûa taûzí: . al-riįađ. 1997.

5. Muћammad 'abdal-raћi:m Ka:fu:d. alqișșa al-qațariįia.( Qatar story) inša:u-ttațaûûur. da:r qațari bin al-fağğa:a du:ћa, ț2. 1982

6. Aћmad 'abdalla al-malik. al-gurfa 405 . mağmu: a qișa:șiija. (The Room number 405) al-riiađ. 1997

7. Aћmad 'abdalla al-malik. aura:q nisa:ja. qișșaș qa.și:ra min ișda:rat (Women's papers. Short Stories)-I -mağlis alûațani lit’’’aqa:fa ûa-t-tura:t' . ț1. 2001.

8. Huda al-ná i:mi. aba:ți:l. (The Herous) da:r al-mașriịia al-lubna:niįia. al-qa:hira. ț1. 2001

9. Nu:ra muћammad farağ. al- țaûa:țim. (El-Tawateem) dar al-kunu:z aladabiįja. ț1. 2001

10. Dalla:I hali:afa. ana: al-įa:smi:na albaįđa: '( The Wight Jasmine) mağmu: a qișșaș. dar 'ulu:m liț-țiba: ûa-n-našr ûataûzi: . ad-du:ћa. ț1. 2002

11. Suvorov M.N. Realizm i mmodernismv hudojestvennoy proze stran Araviyi (Realism and Modernism in Arabian Prose) // Vestn. S.Peterb.un-ta. 2012. Ser.13. Vostokovedeniye. Afrikanistika. Vip.3. P.63-71.

12. Arabskaya Romantiçeskaya proza XIX$X X$ vekov. (Arab Romantic prose of the 19th-2oth centuries)// Sbornik Per. S arab. Predisloviye A.Dolininoy. Leningrad: Hudojestvennaya literature, 1981. - $320 \mathrm{p}$.

13. Kirpiçenko B.N. Yegiptiyanki - avtori I personajî. (Authors and Characters)/ Sb. «Jenšina Vostoka v literature I obšestve». - $\quad$ M.:Institut bostokobedeniye, RAN.2007. - 176p.

14. Zakirat-ul al-mustaqbal musuatu-Ikatiba al-arabiya alfasli assabi'a va aljaziyratu va al-Xalij. (Encyclopedia of
Arab Writers "Memory for the Future) Qohira. 2003. 